\title{
Memory and historical Jesus studies: Formgeschichte in a new dress?
}

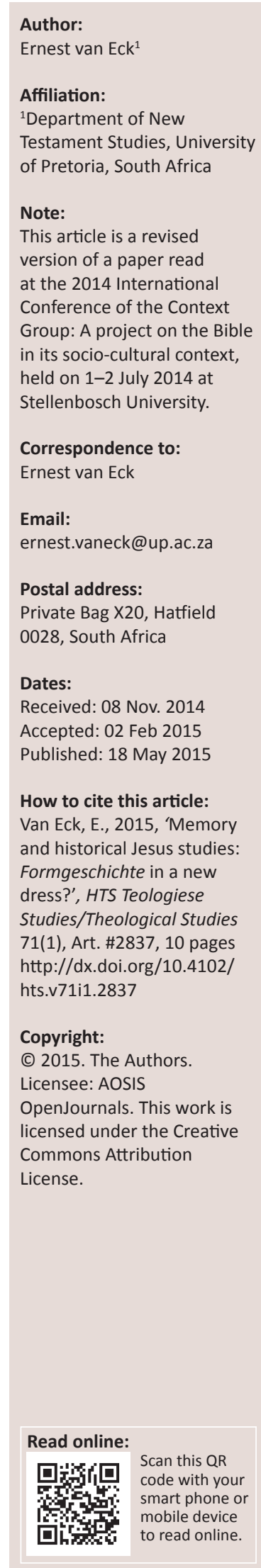

In the quest for the historical Jesus, memory studies are seen as an important breakthrough in the study of the historical Jesus and the way forward in establishing the historicity of the Gospel traditions. This article evaluates the claim made by memory studies by evaluating memory studies' critique on the methodology of the criteria approach. In this evaluation attention is given to the methodological points of departure of memory studies, including an assessment of the few examples memory studies thus far have produced in their investigation of the historicity of the Gospels and the historical Jesus. The conclusion reached is that memory studies are guilty of what they accuse the criteria approach, and thus far have not yet offered a viable methodological alternative to the current criteria approach used in historical Jesus research.

\section{Introduction}

Memory studies, or the so-called 'Jesus-memory-approach' (Keith 2011:155), is the new buzzword in historical Jesus studies. ${ }^{1}$ Memory studies, it is argued, are not only an important breakthrough in the study of the historical Jesus, but also the way forward in establishing the historicity of the Gospel traditions. In advocating this 'new way forward', the current dominant 'criteria approach' - that 'employs criteria of authenticity to sanitize Gospel traditions as authentic before connecting them to the historical Jesus' (Keith 2011:155) - is rendered as the wrong tool (see Hooker 1972:574-581) ${ }^{2}$ for the question under investigation. This critique by Hooker on the criteria approach used in historical Jesus studies has since become a slogan for those who advocate memory studies. Below the direct opposite will be argued, namely that memory studies are the wrong tool to use since it is a historical and not a literary tool. The reason for this assessment of the criteria approach is articulated by Le Donne (2012b) as follows:

$[T]$ he notion of an 'authentic' dominical tradition creates a false dichotomy between memory and interpretation. As such, it is the conventional use of criteria ${ }^{3}$ that must be replaced by a more sophisticated historiography (emphasis original, pp. 4-5)

According to Keith (2012b:47), the term 'criteria of authenticity' is a misnomer, and the stubborn focus of current historical Jesus research on these criteria - a continuance of a historical-critical methodology that is essentially form-critical - has resulted in the current methodological quagmire historical Jesus research finds itself in. Because 'the criteria of authenticity, even in modified forms, ${ }^{4}$ simply cannot deliver what they are designed to deliver' (Keith 2012b:26), a new approach is needed, namely memory studies (Keith 2012b:47).

At the 2013 Annual Meeting of the Society of Biblical Literature in Baltimore, one of the sessions, the 'Historical Jesus Section' (Session S25-315, titled Memory studies and historical Jesus research) was devoted to the current memory studies versus criteria approach debate. At this session two of the prominent proponents of the use of memory studies in historical Jesus research, Chris Keith (2013) and Rafael Rodríguez (2013), argued for memory studies as the way forward in historical Jesus research, and Paul Foster (2013) questioned the applicability of memory studies to

\footnotetext{
1.See especially the contributions by Keith (2011), Le Donne (2011), Rodríguez (2013) and Schröter (1996, 2013)
}

2.In an article published in 1972, Hooker argued that the tools being used in historical Jesus studies to uncover the authentic teaching of Jesus (i.e., Formgeschichte) cannot do what is required of them because Formgeschichte is a literary and not a historical tool (Hooker 1972:570).

3.In a recently edited volume, Keith and Le Donne (2012), two of the prominent advocates of memory studies, invited inter alia supporters of memory studies to critically engage with the criteria being used in the criteria approach. The criteria discussed (and
discarded) are the criteria of dissimilarity (Winter 2012:115-131; see also Le Donne 2012b:12; Allison 2012:188); embarrassment discarded) are the criteria of dissimilarity (Winter 2012:115-131; see also Le Donne 2012b:12; Allison 2012:188); embarrassment
(Rodriguez 2012:135-151; see also Le Donne 2012b:14); Semitisms and Semitic influence (Stuckenbruck 2012:73-94; see also Le Donne 2012b:14); multiple attestation (Goodacre 2012:152-169; see also Le Donne 2012b:16; Schröter 1996:158); multiple forms (Le Donne 2012b:14); multiple attestation (Goodacre 2012:152-169
Donne 2012b:16) and coherence (Le Donne 2012a:95-114).

4.See Keith (2012b:40-47) for a discussion of recent attempts to rehabilitate the criterion of dissimilarity by Wright, the criterion of plausibility by Theissen and Winter, and memory refraction by Le Donne. According to Keith (2012b:47), these rehabilitation projects in essence point to the abandonment of the criteria approach. 
answer questions on the historical Jesus. Zeba Crook (2013) ${ }^{5}$ also argued for the use of memory studies, but concluded that when memory studies are consistently applied in the search for the historical Jesus, we again are treading into No Quest waters. ${ }^{6}$

The aim of this article is to reflect on the claim of memory studies to be the way forward in historical Jesus studies. Although the main focus of the article is to evaluate the critique of the methodology of the criteria approach to memory studies, attention is also given to the methodological points of departure of memory studies, including an assessment of the few examples memory studies thus far have produced in their investigation of the historicity of the Gospels and the historical Jesus. It will be argued that memory studies are not the way forward in historical Jesus research. On the contrary, memory studies are nothing else than Formgeschichte in a new dress.

As conversation partners, the works of the participants in the 2013 Society of Biblical Literature's Annual Meeting's session 'Memory studies and historical Jesus research' are chosen (see Crook 2013; Foster 2012, 2013; Keith 2011; 2012a, 2012b; Rodríguez 2012, 2013), as well as the works of Le Donne (2011; 2012a; 2012b) and Schröter (1996; 2012; 2013) also prominent advocates of the use of memory studies in historical Jesus research.

\section{Memory studies' critique on the criteria approach}

Memory studies' main points of critique of the criteria approach are twofold: Firstly, its indebtedness to Formgeschichte (form criticism), and secondly, the discarding of the importance of the Gospels as narratives ('theological interpretations of the historical Jesus as the crucial links to the past'; see Keith 2012b:47) by identifying individual 'authentic' (earlier) units of tradition in the Synoptic Gospels.

Firstly, more on the criteria approach's so-called indebtedness to Formgeschichte. According to Keith (2011:157; see also 2012b:31, 32), 'the entire enterprise of criteria of authenticity is dependent upon a form-critical framework' (emphasis original; see also Schröter 2012:50). Keith (2011:157) continues: 'For, the criteria approach adopts wholesale the form-critical conception of the development of the Jesus tradition and thus its method for getting "behind" the text' (Keith 2011:157).

To understand this critique levelled by Keith at the criteria approach, it is necessary to look in more detail to Keith's understanding of Formgeschichte. According to Keith (2011:

\footnotetext{
5.The author extends his gratitude to Rodríguez, Foster and Crook for making thei presentations available. For an audio version of the presentations and the discussion during the session, see Keith, Crook, Rodríguez \& Foster (2013).

6.The Jesus Blog hosted by Keith and Le Donne, labelled this session as the so-called 'Blow Up in Baltimore' (Le Donne 2014). For Le Donne's assessment of the session, see Le Donne (2014).
}

157-160), the presuppositions of Formgeschichte are the following: (1) The interpretations of Jesus in the Gospels (which Rodríguez [2013:1] calls 'commemorative artifacts') came from later Christians, not from the earliest stage(s) of the oral tradition (Keith 2011:159); (2) the impetus for the shaping of the oral Jesus tradition (that was neither textualized nor narrativised) was early Christian existence itself, especially the missionary activity of preaching (Keith 2011:159); and (3) the Jesus traditions found in the Gospels thus are due to the theological convictions of the believing communities that, because of specific Sitze im Leben, influenced both the content of the tradition (individual Jesus traditions) and the means of its delivery (forms) (Keith 2011:159). As such, the Synoptic Gospels are a mix of earlier oral traditions and later interpretive traditions. Based on this conviction, the development of the Gospel tradition is understood as being evolutionary in character, 'whereby the earliest oral tradition absorbed elements of the early Church's faith on an inevitable path toward the tradition's textualization' (Keith 2011:159; emphasis original). To identify the individual units of traditions that comprise the Synoptic Gospels, Formgeschichte developed a methodology to identify the oral (earlier) traditions in the written tradition (Gospels). Scholars who use Formgeschichte thus believe that one can separate the pre-literary oral Jesus tradition from the later interpretations of the Jesus tradition by the Gospel writers and their communities (Keith 2011:160).

According to Keith (2011:163), the indebtedness of the criteria approach to Formgeschichte becomes clear when the primary task of the criteria approach - to identify authentic pristine traditions in the Gospels and separate them from later interpretive (inauthentic) material - is compared with the presuppositions of the Formgeschichtliche approach. The criteria approach, as depicted by Keith, assumes that (1) the written Gospels consist of authentic and inauthentic material; (2) the authentic material was absorbed by later early Christian interpretive traditions; and (3) it is possible to distinguish between authentic and inauthentic material. As such, the 'criteria approach to the historical Jesus mirrors the form-critical approach to the Jesustradition' (Keith 2011:163). The only difference between the two approaches is that the criteria approach substituted the pre-literary tradition with that of the historical Jesus.

According to the advocates of memory studies, the problems concerning the criteria approach are multiple. Apart from the fact that the criteria approach borrows its conception of the Gospel tradition from a methodology that New Testament scholarship largely abandoned decades ago' (Keith 2011:165; emphasis original), memory studies contest the possibility to distinguish between authentic and inauthentic material. According to Crook (2013:11-12; see also Kirk \& Thatcher 2012:25-42), the criteria approach misses the possibility that Jesus delivered any speech or story multiple times, with each delivery being different and therefore the 
non-existence of any one authentic form of a performance. ${ }^{7}$ Also, and more importantly, because 'all remembering requires interpretation and framing, separating tradition (what is remembered) from interpretation (how it is remembered) is flatly impossible' (Crook 2013:12). Because of this, there is no thing such as 'authentic' and 'inauthentic' traditions (memories). As put by Keith (2011:170): 'Scholars cannot separate Jesus traditions into authentic and inauthentic bodies of traditions because all Jesus traditions belong, in a real sense, to both categories'. Keith (2011) elaborates:

[T]he development of the Jesus tradition into the written Gospels was not a process whereby inauthentic interpretations were added to an authentic core of historically pristine material until the final product was a mix of both wherein each is easily identifiable. Rather, it was a process whereby there were only ever interpretations/memories of the past to begin with, to which other interpretations ... were added until the final product was a result of that interpretive activity. Parsing out the respective influences of the present and the past in this process is much more complex than the criteria approach allows. (p. 171)

Memory studies thus not only have a problem with the authentic or inauthentic perspective of the criteria approach, but also its past versus present dichotomy, especially in the case where individual units of authentic traditions are removed from their interpretive frameworks in the Gospels. As Keith (2012b:39) observes:

The authentic/inauthentic dichotomy is false precisely because, in memory, the past is always packaged in interpretive frameworks borrowed from the present. If not for those frameworks, the past would not survive at all. (p. 171)

For memory studies, because the past is always packaged in interpretive frameworks borrowed from the present, the methodological implication for the study of the historical Jesus is clear: Investigating the historical Jesus should concentrate on the whole (the Gospel narratives), not on the details (individual 'authentic' units; see Hooker 2012:xv). The time has come to throw away the tools of the Formgeschichte,

\footnotetext{
7.This point of view is also advocated by Snodgrass $(2008: 222)$ in his research on the parables, although not using memory studies as the approach to analyse the parables. Simply making this statement, without supporting evidence, is nothing less than historical positivism. The criteria approach, by using Redaktionsgeschichte linked with some of the criteria proposed by the criteria approach (e.g., multiple attestation), at least can put a case forward that Matthew 18:12-14 and Luke 15: 4-7 most probably made use of the same written tradition. In Matthew 18:14 the

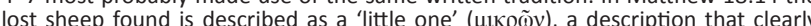

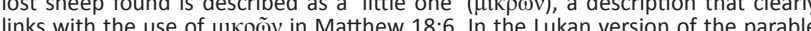
links with the use of $\mu 1 \kappa \rho \tilde{\omega} \nu$ in Matthew 18:6. In the Lukan version of the parable the redactional hand of the narrator can also be indicated: The lost sheep found is described as a sinner ( $\alpha \mu \alpha \rho \tau \omega \lambda \tilde{\omega}$; Lk 15:7), that, in this case, clearly refers back to Luke 15:1-2 where the Pharisees and scribes protest because Jesus is eating with sinners (see $\alpha \mu \alpha \rho \tau \omega \lambda$ oì [Lk 15:1] and $\alpha \mu \alpha \rho \tau \omega \lambda$ ov̀ [Lk 15:2]). In both cases it can be argued that Matthew and Luke most probably applied the parable found in the written tradition in a way that supports the message they wanted to convey. To state that we have multiple memories because of different oral performances by Jesus is not enough. Without substantiation, it is a mere sweeping statement that fits memory approach's historical positivist understanding of the development of the Jesus tradition. The historical-positivist approach of memory studies is clear in the following statement by Keith (2011:171), in which the transmission of traditions about Jesus developed in the following way, and only in this way: 'Rather, it was a process whereby there were only ever interpretations/memories of the past to begin with, to which other interpretations - that grew from, approved of, disagreed with contradicted, but in the least were in dialogue with and thus to some degree with, contradicted, but, in the least, were in dialogue with and thus to some degree a result of that interpretive activity' (emphasis original).
}

8.Also see Keith (2011:170): 'All tradition - all memory - is an indissoluble mix of the past and the present. The present would have nothing to remember if it were not for the past; the past would not be capable of being remembered if it were not for the frameworks of the present.' and opt for 'common sense' (Hooker 2012:xvii). Sayings or parables of Jesus, isolated from their narrative contexts, cannot be 'historically examined at all' (Schröter 2012:65). The Gospel narrative, on the other hand, 'gives us interpretations of events on which we can launch our own images of the past' (Schröter 2012:65). These narratives, according to Schröter (2012):

Give impressions of what was regarded as significant, meaningful, and distinctive of Jesus.... The general outline [of these narratives] might be more characteristic for how Jesus was perceived by his contemporaries than the particular unit isolated by form-critical investigation and put to the test for its authenticity. (p. 65)

Moreover, concentrating on the Gospel narratives will enable historical Jesus scholars to interpret Jesus within his context (Schröter 2012:53). The narrative settings in the Gospels are not only part of the literary portraits of Jesus in the Gospels, but also belong to the historical truth claims made of Jesus (Schröter 2012:65). As Schröter observes (2012): The memory approach is based on:

$[T]$ he growing awareness that a portrait of the historical Jesus has to be designed as part of the Judaism of the HellenisticRoman period in its Galilean shape.... This approach, therefore, aims at interpreting Jesus within his context.... Rather, it is the general perception of the historical background [which we find in the gospel tradition] against which Jesus' activity has to be interpreted. (pp. 52, 57)

\section{The Jesus-memory approach}

Before reflecting on memory studies' negative assessment of the criteria approach, a brief description of the salient features of 'the Jesus-memory approach' as 'a better means of postulating the actual past of Jesus' (Keith 2011:156), is necessary. In following Halbwachs, Keith (2011) describes the foundational argument and primary task of social memory as follows:

$[M]$ emory is not a simple act of recall, but rather a complex process whereby the past is reconstructed in light of the needs of the present .... No memory is possible outside frameworks used by people living in society to determine and retrieve their recollections. By focusing upon the social formation of memory in the present ... the primary task of social memory theory is to conceptualize and explain the various manners in which cultures (and individuals as culture-members) appropriate the past in light of, in terms of, and on behalf of the present. (p. 168)

Le Donne (2011:106) describes this process of memory (commemorating) as refraction. Making use of the work of social memory theorists like Halbwachs, Assmann and Schwartz, ${ }^{9}$ Le Donne (2011:107) understands refraction as 'a natural, necessary, and benign function of memory selection' (emphasis original). The reason for this, Le Donne (2011:22-23) argues, is because of the fact that perception is always filtered through familiar thought categories. As such, memories are always shaped by external environs and constraints unique

9.For a concise description of the salient features and development of the theory on social or collective memory, see Van Eck (2011b:201-203). 
to a specific historical context (Le Donne 2011:23, 28). Put differently: 'Historians tell the stories of history from a particular contemporary perspective' (Le Donne 2011:34). Memory thus always goes hand in hand with perspective and interpretation (Le Donne 2011:25), and does not preserve the past, 'it can only perceive how the past has impacted on the present' (Le Donne 2011:26). History, therefore, 'only includes the past that has been interpreted through memory,' and that 'which has not been remembered is not history' (Le Donne 2011:34). Understood from a social memory perspective, history thus is not really about the past - 'it is about defining the present and who we are' (Le Donne 2011:35). Also, the 'more significant a memory is, the more interpreted it will become' (Le Donne 2011:37). What Keith and Le Donne argue, in sum, is that social memory investigates the question 'who wants whom to remember what, when and why' (see Van Eck 2011b:204); memory is reshaped with each new interpretation (or application) in a new (later) situation with the aim of cohesion and the self-understanding (identity) of groups (Van Eck 2011b:201). ${ }^{10}$ Or, as put by (Rodríguez 2013:8): 'Jesus' followers always remembered him for their own reasons and in their own situations'.

The above understanding of social memory, when applied to the study of the historical Jesus:

$[B]$ ring $[s]$ the old discussion of the search for the historical Jesus to a close and call[s] for a new discussion, one that forestalls and leaves behind any talk of 'mixture', 'authenticity', 'inauthenticity', and the 'criteria' for distinguishing the two. (Rodríguez 2013:5)

Historians simply cannot 'separate Jesus' past from his followers' present by prying a tradition from its literary and historical context' (Rodríguez 2013:5). Moreover, historians have to account not only for the production of the memories about Jesus, but also for the reception of these images, regardless of those images' purported authenticity (Rodríguez 2013:6). With this as cue, it is possible to indicate that even those traditions that do not actually go back to Jesus can be understood as accurately reflecting the Jesus of history (Rodríguez 2013:8).

\section{Methodological reflections Memory studies' understanding of Formgeschichte}

The social memory approach's first main point of critique of the criteria approach is the supposed use of form criticism (see Crook 2013:11; Keith 2011:156, 163; Schröter 2012:50). ${ }^{11}$ This critique is based on two misconceptions. Firstly, the proponents of memory studies' understanding of what

10. Below it will be argued that this understanding of social memory indeed can be applied to the understanding of memories such as the written Gospels.

11.See Keith (2011:157; emphasis original), who states that 'the entire enterprise of criteria of authenticity is dependent upon a form-critical framework' to such an extent that the criteria approach to the historical Jesus 'mirrors the form-critical approach to the pre-literary Jesus tradition so much so that the former has simply exchanged "the original historical tradition" ... for "the historical Jesus"' (Keith 2011:163). Crook (2013:11) argues in the same vein: "According to Keith and Le Donne, and a small group predecessors, traditional historical Jesus studies is characterized by a number of features: the quest to reconstruct the original, is characterized by a number of features: the quest to reconstruct the original,
authentic words of Jesus using criteria the foundation of which is form-criticism.'
Formgeschichte entails is not correct, and, secondly, the 'criteria approach' (that can only refer to either the New Quest or the Renewed or Third Quest, the only two quests that can be linked to the use of criteria) does not make use of Formgeschichte, but Redaktionsgeschichte. ${ }^{12}$

Formgeschichte can be seen as the result of the insights of Traditionsgeschichte. Traditionsgeschichte (as a development from Literarkritik) argues that the words and deeds of Jesus were orally transmitted, starting with the reports of eye and ear witnesses. These reports soon became what are now labelled as 'oral traditions'. Formgeschichte, ${ }^{13}$ as an extension of Traditionsgeschichte, argues that these oral traditions were transmitted in specific forms because of Sitze im Leben in the early believing community. Keith (2011:159) is thus correct when he understands form criticism as the exegetical method that is interested in the shaping of the oral tradition (that was neither textualized nor narrativised) in the earliest believing communities because of different Sitze im Leben. He is also correct that exegetes who make use of Formgeschichte believe that one can separate the pre-literary oral Jesus tradition from the later interpretations of the Jesus tradition by the Gospel writers and their communities (see Keith 2011:160).

The problem with Keith's understanding of form criticism, however, is that he links this approach with the criteria approach, which is not correct. The criteria approach - which must either refer to the New Quest of the Renewed or Third Quest - takes inter alia as its point of departure Redaktionsgeschichte, the exegetical method that 'studies the contribution of the final writer who composed a literary work on the basis of the sources' (Krentz 1975:51). The focus of the criteria approach is the literary text, and not the oral traditions that lie 'behind' the text. Historical Jesus studies that make use of specific criteria are not interested in identifying oral traditions within the written tradition, as Keith (2011:158) argues. The criteria approach is rather interested in identifying the most probable earliest tradition in the written tradition, and for this Redaktionsgeschichte is used, plus the use of certain criteria (e.g., early, independent and multiple attestation; see Crossan 1991:xxxi-xxxvi). Interestingly, Keith (2011) supports this depiction of the

12.The history of historical Jesus research can be divided into five periods: The preQuest (before 1778), the Old Quest (1778 [Lessing's publication of Reimarus' seventh fragment titled 'On the intention of Jesus and his disciples'] to 1906), the No Quest (1906 [the publication of Schweitzer's Von Reimarus zu Wrede] to 1953), the New Quest (1953 [the date of Käsemann's now famous lecture 'The problem
of the historical Jesus'] to 1985), and the Renewed or Third Quest (1985 [the of the historical Jesus'] to 1985), and the Renewed or Third Quest (1985 [the
publication of Sanders' volume Jesus and Judaism and the year of the first meeting publication of Sanders' volume Jesus and Judaism and the year of the first meeting
of the Jesus Seminar] until the present; see Tatum 1999:91-109). Importantly, of the Jesus Seminar] until the present; see Tatum 1999:91-109). Importantly, Tatum (1999:109) indicates that periods two to four in historical Jesus research
overlap respectively with the periods during which source criticism, form criticism, overlap respectively with the periods during which source criticism, form criticism,
and redaction and narrative criticism were popular. As such, form criticism was the and redaction and narrative criticism were popular. As such, form criticism was the
main exegetical method used in the period of the No Quest. Advocates of memory studies are therefore not correct to assume that the criteria approach uses form criticism. The use of criteria was introduced during the New Quest, and extensively developed in the Renewed or Third Quest.

13. Krentz (1975:50) defines form criticism as follows: 'Form criticism identifies and classifies units of (oral) material and relates them to their presumed sociological setting in earlier life in the community' (emphasis original). Tatum (1999:45) defines form criticism in the same vein: 'Form criticism can be defined as the discipline that seeks to understand the Gospel tradition as it was transmitted orally, before it was written down' (emphasis original). See also Catchpole (1997:168): 'Form criticism recognizes that source material may have been in written form, but that it was not necessarily so. It aims therefore ... to establish the earliest form of ... units, to classify them on the basis of "family likeness", and, by the exercise of informed imagination, to posit for each a setting and a purpose in the life of the community' (emphasis original). 
methodology of the criteria approach when he states the following:

According to the logic of the criteria, the authentic body of Jesus tradition allows scholars to get 'behind' the written Gospel texts with some surety, to glimpse the historical Jesus who existed prior to the interpretations of him reflected in the written narratives. Scholars thus connect portrayals of Jesus in the written Gospels with the historical Jesus only once they have passed through the criteria of authenticity. (p. 162)

Clearly, as attested by the above quote from Keith (one of the prominent proponents of the memory studies approach), the criteria approach is not interested in identifying oral traditions that may lie behind the text. It rather makes use of literary tools with the aim to identify the way in which a redactor may have changed the source(s) used. When this methodology is applied, for example, to the same narrative in the three Synoptic texts, the criteria approach believes that it is possible (albeit to a limited extent) to identify how a specific source was changed or theologically used by a specific narrator. That the criteria approach does not use form criticism, and is not interested in the oral traditions behind the text, is also attested by Rodríguez, another prominent advocate of memory studies: 'Redaction-critical research has dominated NT scholarship for over five decades. As a method, redaction criticism has thrown the creative work of the evangelists into particularly sharp relief' (Rodríguez 2013:6). Rodríguez not only confirms that the criteria approach uses Redaktionsgeschichte as its point of departure, ${ }^{14}$ but also that, in the criteria approach, the written text is the focus of investigation.

Therefore, whereas the form-critical approach aimed to identify the oral traditions (shaped by, or having originated in the Sitz im Leben of early Jesus communities) behind the written text, the criteria approach focuses on the written text by using Redaktionsgeschichte as point of departure. The criteria approach thus cannot be labelled as form-critical in approach. On the contrary, most scholars using the criteria approach believe that one cannot go beyond the written text into the oral phase of the narrativised and textualized written sources; what is available as sources are the written texts, and nothing else. In a study of Matthew, for example, the criteria approach will therefore argue, in the case where the two (or four) source theory is accepted as solution to the Synoptic problem, ${ }^{15}$ that the majority of the sources used by the narrator were not oral traditions behind the text, but

14.See also Le Donne (2012b:16) who, when critically discussing the criteria of Semitisms, Semitic influences, multiple attestation, and multiple forms used by some scholars that use the criteria approach, remarks that these criteria 'developed in parallel to form criticism, but did not emerge from it.' Even Schröter (1996:157), another ardent advocate of the memory studies approach, opines that Crossan, for example, uses 'an advanced version of the form critical approach in dealing with the synoptic tradition.'

15.See in this regard Kloppenborg (2008:38-40), who argues that the two source theory, while keeping in mind that it is only a hypothesis and a simplifying of the actual relationships among the Gospels, works. It does not only make maxima sense of most of the data in the Synoptic Gospels, but also provides an effective explanation that aids our understanding of the data. As claimed by Kloppenbor (2012:40): 'To assume that Matthew and Luke used Mark independently supplementing, improving, explaining, and qualifying Mark, in fact makes sense for most of the data of the Synoptic Gospels. It works. It produces an account of the Gospels that makes sense. To assume that Matthew and Luke used a second document to supplement what they had from Mark in fact makes for an efficient explanation of the data. It works' (emphasis original). written sources such as Mark and Q.M (Matthean Sondergut), of course, could also have included oral traditions. ${ }^{16}$

In short, the criteria approach is not interested in identifying oral (earlier) traditions in the written tradition (Gospels) by using form criticism as argued by some of the prominent proponents of memory studies. It rather argues that the interpretations of Jesus in the Gospels come from later Christians, not from the earliest stage(s) of the oral tradition. And in this lies an ironic twist: What the memory approach accuses the criteria approach of, is what the memory studies approach is guilty of. Keith (2011), for example, when emphasising the need to supplant the criteria approach with the memory studies approach, states:

Therefore, as a research paradigm, the Jesus-memory approach insists that a proper consideration of the transmission of Jesus tradition as the appropriation of collective memory must account not only for the role of the present in shaping the past, but also the role of the past, and past interpretations of the past, in shaping the present. (p. 169)

From this statement by Keith the difference between the two approaches is clear: Whilst the criteria approach believes that the only sources we have of the past are the written texts, the memory studies approach believes that the 'past interpretations of the past' (what Le Donne calls refraction; see also Schröter 1996:155) should (also) serve as source to investigate the historical Jesus. These 'past interpretations of the past', in my opinion, are nothing else than the oral traditions from critics who seek to identify 'behind' the written texts. Moreover, with this historical positivist understanding of the development of the Gospel tradition ${ }^{17}$ (as evolutionary in character), the memory studies approach takes as its point of departure what it accuses the criteria approach of, namely that the oral tradition (refraction) absorbed 'elements of the early Church's faith on an inevitable path toward the tradition's textualization' (Keith 2011:159). As such, it is the memory studies approach, and not the criteria approach, that believes that earlier oral traditions or memories (refractions) are present in the written tradition (Gospels) that must be taken into account

16.Kloppenborg (2012:103-105) makes a strong case that the Synoptics made use of written and not oral traditions. In quoting DeConick, Kloppenborg (2012:103104) argues that data suggest 'that when the text in question shows a tendency to preserve words of Jesus more accurately than the surrounding narrative the author likely had consulted a written source.... Other signs of literary dependence author likely had consulted a written source .... Other signs of literary dependence include verbatim strings of sixteen or more words and exact reproduction of sayings and narratives. Since we have multiple examples of this in Q, Kloppenborg (2012:105) concludes that it is 'virtually unavoidable that Matthew and Luke had contact with a written source for their double tradition material, since it is only by this means that one can account for the significant number of strings of verbatim agreements in excess of sixteen words.' Kloppenborg (2012:106) continues: 'Thi implies that in relation to the Synoptic Problem issue of whether $Q$ was written o not, the high verbatim agreement between Matthew and Luke in a large number of pericopae virtually necessitates that they had recourse to a document, not oral memories; their general agreement in the relative sequencing of $Q$ materials points in the same direction; and instances of disagreement hardly authorize us to partition ' $Q$ ' into written and oral components, still less to suppose that the allegedly oral parts represent reliable memories of Jesus.' This case can also be made for several of the narratives in Mark, used by Matthew and Luke (see, e.g., Mk 4:5-6; Mt 13:5-6).

17.According to Le Donne (2012a:95; 2012b:3) the criteria approach's idea of authenticity and the development of criteria by which the authentic traditions can be identified 'emerged from the presuppositions of historical positivism.' The same can be said of the presuppositions of the memory approach, namely that 'memory does not preserve the past' (Le Donne 2011:26). Why, for example, is it 'memory does not preserve the past' (Le Donne 2011:26). Why, for example, is it
not possible that some of Jesus' sayings (e.g., the aphorisms in Mk 10:25; 12:17) not possible that some of Jesus' sayings (e.g., the aph
could have been remembered as Jesus uttered them? 
when studying the historical Jesus. Put differently: Memory studies, when applied to the study of the historical Jesus, are nothing else than Formgeschichte in a new dress.

The problem here is that we simply do not have these earlier refractions of the traditions stemming from the words and deeds of Jesus. ${ }^{18}$ As put by Schröter (1996:158), ironically an advocate of the memory studies approach: '[O]ne cannot go beyond the different versions and contextualizations of a saying into the oral phase of transmission.' The only sources (or memories) we have are the extant written texts available to the historian. It is therefore not the criteria approach, as Keith (2011:170) argues, that is looking for 'unicorns, the lost city of Atlantis, and the pot of gold at the end of the rainbow,' but memory studies. As the direct opposite, historical Jesus studies using the criteria approach at least have available sources to work with - sources, when scrutinised in terms of the theological frameworks in which they are used with the aid of chosen criteria, can postulate that some of the traditions taken up in these written sources can bring us closer to the earliest layer of the Jesus tradition.

Two final remarks: Firstly, during the earlier mentioned session at the 2013 Society of Biblical Literature (SBL) meeting, Crook (2013:12) made a strong case that when memory studies, as advocated by the memory studies school, are applied to the study of the historical Jesus the ultimate consequence will be, as was the case with the Old Quest that used form criticism, a new No Quest. If in fact it is true that memory is not retrieved but reconstructed (as form criticism also argues), and in this act is prone to distortion, as Crook (2013:3) argues, then memory theory ends up not in confirming the reliability of the Gospels, but questioning their reliability. It also means that it is impossible to distinguish between real and distorted memories (Crook 2013:12). For Crook (2013):

[T] he value of memory theory to historical Jesus research is really a dis-value - it does not refine our previous positivistic criteria, allowing us better to distinguish between authentic and inauthentic Jesus material. Neither does it provide a new route by which to discover authentic Jesus material. Rather, I suggest, it pushes us ever further away from certainty, from confidence in assessing authentic material, and in distinguishing it from inauthentic material. (p. 13)

Secondly, Hooker is not correct when she states that the criteria approach (which she incorrectly labels as form criticism) uses a tool to study the historical Jesus that cannot do what is required because it is 'a literary and not a historical tool' (Hooker 1972:570). Because the criteria approach studies literary texts, a literary tool is needed to postulate something about the historical Jesus. Memory studies, on the other hand, use a historical tool to analyse literary texts.

18.Foster $(2013: 6-7)$ comes to the same conclusion: "Moreover, the oral period of Jesus tradition, while theoretically a likely stage of the earliest transmission of Jesus esus material, is in reality unretrievable and inaccessible. The following remark by Foster (2012:205) can also be noted in this regard: 'Moreover, those who approach the Jesus traditin transmission for those traditions. However, what is questioned is whether the ora stage is accessible or recoverable in any meaningful way given that all the surviving evidence is preserved in written form' (emphasis added).
And this indeed, is the wrong tool. As put by Foster (2013:7): 'To use memory studies to address this question is simply a mismatch between the tool or method being used and the question under investigation'. A stubborn use of this approach can only lead to a real methodological quagmire in historical Jesus research.

\section{Memory studies' emphasis on the literary portraits of Jesus in the Gospel narratives}

Memory studies' second main point of critique of the criteria approach is the so-called discarding of the importance of the Gospels as narratives by identifying and interpreting individual 'authentic' (earlier) units of tradition in the Synoptic Gospels in isolation from their contexts. The following quotes from Schröter (2012) summarise memory studies' critique of this aspect of the criteria approach, as well as the way in which the Gospel narratives should play a role in the subject under investigation, as follows:

It is even hard to imagine how sayings or parables isolated from their narrative contexts can be historically examined at all .... They give us interpretations of events on which we can launch our own images of the past .... The general outline [of the Gospels] might be more characteristic for how Jesus was perceived by his contemporaries than the particular unit isolated by form-critical investigations and put to the test for its authenticity .... [The] narrative [settings are] therefore part of the literary portraits of Jesus in the Gospels and at the same time belong to their historical truth claims .... They claim not to be mere fiction but narratives about events that actually happened in the past. (pp. 64-66) ${ }^{19}$

The diminishing dominance of the 'criteria approach' is not at least a consequence of the growing awareness that a portrait of the historical Jesus has to be designed as part of the Judaism of the Hellenistic-Roman period in its Galilean shape, and, at the same time, as an endeavor which leads to the formation of a new religious movement. This approach, therefore, aims at interpreting Jesus within his context. (Schröter 2012:52; emphasis original)

What Schröter argues is echoed by Keith (2011) as follows: Since all memory is an indissoluble mix of the past and the present:

[The] present would have nothing to remember if it were not for the past; the past would not be capable of being remembered if it were not for the frameworks of the present. (p. 170)

Apart from the fact that the Gospel writers were not contemporaries of Jesus (with Mark being the closest, but still at least forty years later than the life of the historical Jesus), and that not all of the Gospels (definitely not Luke) portray the historical Jesus 'in its Galilean shape', it can be argued that there is no real difference between memory studies and the criteria approach's understanding of the Gospels as narratives (frameworks) that interpret (memorialise or commemorate) the ministry of the historical Jesus.

The latter statement needs explanation. Schröter's claim that the narrative settings of the Gospels (i.e. literary portraits of

19.See also Keith (2012b:47), who states that the Gospel narratives are "theological interpretations of the historical Jesus as the crucial links to the past.' 
Jesus) include historical truth claims (narratives about words and deeds of Jesus) that actually happened in the past is not a new insight. The Gospels, as narratives, can be described as three-worlds-in-one; a textual, referential and contextual world. The textual world of each of the Gospels, that is, each Gospel's specific literary portrait of Jesus, differs from one another. Mark, in broad, depicts Jesus as the suffering Messiah, Galilee and Jerusalem are pictured as opposing centres of interest, and one of its main foci is the following of Jesus that entails self-sacrifice and suffering (see Van Eck 2012:64-90). Matthew and Luke's pictures of Jesus do not only differ from that of Mark, but also include several narratives not found in Mark, that impact decisively on their respective literary portraits of Jesus. Moreover, in these three textual worlds the disciples of Jesus are pictured differently. Mark's disciples seem to be a total failure, in Matthew the disciples' loyalty towards Jesus is pictured as alternating between faith and little faith, and in Luke the disciples are consistently described in a positive way. The same can be said of Jesus' relationship with his opponents (Pharisees and scribes) in these three textual worlds. In Mark, for example, Jesus' adversaries on Galilean soil are the scribes and Pharisees 'from Jerusalem' (see e.g., Mk 3:22; 7:1), which is not the case in Matthew and Luke. In short, the literary portraits of Jesus, the disciples, and Jesus' relationship with his adversaries in the three Synoptic Gospels, although including historical truth, not only differ from one another, but at times differ in such a way that these literary portraits cannot be reconciled.

The referential world of the Gospels refers to the words and deeds of the historical Jesus (traditions). Mark, in composing his Gospel, most probably used some pre-Markan material (e.g. Mk 2:1-3:6; 12:13-37a; 14:1-15:47, and the two narrative cycles in Mk 4:35-36:44; Mk 6:45-8:10) and other traditions (written or oral) known to him. Matthew and Luke, in terms of the four source theory, used Mark and Q, and Sondergut known as $\mathrm{M}$ and $\mathrm{L}$. Thus, although these three narratives have the same broad structure (with Matthew and Luke following Mark's structure), at times used the same sources (the so-called triple-tradition), and in the case of Matthew and Luke, added the double-tradition $(\mathrm{Q})$ that only includes words of Jesus, their respective pictures of Jesus are not the same.

Why? Because the contextual worlds (social location of the intended hearers) of the three narratives differ. ${ }^{20}$ This then, is the reason why the textual worlds of the three narratives differ. The social world of Mark's first hearers, for example, most probably included some aspect of persecution, and, because of this situation, they did not understand why following Jesus implied suffering. To address this situation, Mark filters the referential world (sources used) through the Gospels' contextual world, which resulted in a specific textual world (his literary portrait of the ministry of the

20.Kloppenborg (2012:132) concurs with the influence that the contextual worlds have on the textual worlds of the Gospels: ' $[A]$ s tradition moves from one social domain to another, we should expect not only alterations due to the vagaries of domain to another, we should expect not only alterations due to the vagaries of
memory, but also alterations that are due to the varying social registers in which the tradition is performed.' historical Jesus). ${ }^{21}$ As such, the picture of the disciples in Mark most probably mirrors the lack of dedication of the Gospel's addressed receivers (Jesus followers). Put differently: The narrative frameworks of the Gospels (textual worlds) does not reflect the reality of the world of Jesus, but an interpretation of that reality in terms of the historical realities of the different Gospel audiences (contra Keith 2011:170; Schröter 2012:68). ${ }^{22}$

Understood from this perspective, the Gospel narratives are a mix of received traditions, interpreted from a postPaschal perspective for a specific audience, at a specific time in a specific location and social situation, for a specific reason. To address the problems, experiences and needs of these audiences, the Gospel writers told (remembered) or constructed the past in light of the needs of the present in the form of narratives (memories) intended for social formation in the present (see again Keith 2011:168). ${ }^{23}$ To reach this conclusion, memory studies are not needed. It is not a new insight; it has been the point of view of the criteria approach since its use of Redaktionsgeschichte in the New Quest and Renewed or Third Quest. ${ }^{24}$ Moreover, this makes the Gospel narratives 'memory makers', that is, interpretations of the historical Jesus. ${ }^{25}$

Because of this understanding of the textual world of the Gospels, the criteria approach argues that it is necessary to, through the text, get behind the text. ${ }^{26}$ This can be illustrated with a simple example: A Gospel writer, when placing a tradition about Jesus in a specific narrative context, creates

21.Schröter (2013:40) understands this relation between the textual and referentia worlds of the Gospel narratives in the same way, stating that when interpreting the Gospel narratives 'consideration must be given to the relation between the text-world and the extra-textual reality of the activity of Jesus' (see also Schröter 2013:42). The only difference between Schröter and the argument above is that Schröter replaces the terms textual and referential world respectively with 'textworld' and 'extra-textual reality'. Schröter (2013:94) also agrees with the above explained relationship between the textual, referential and contextual worlds of the Gospels: 'The integration of the sayings tradition in the biographicalrecollecting Jesus tradition distinguishes itself by the fact that it narratively [textual recollecting Jus tratively [textual world] unpacks the meaning of Jesus and thereby mediates between the time Jesus [referential world] and the author's own time [contextual world]' (see also
Schröter 2013:34).

22.This is clear from the following statement by Schröter (2012:68): 'Rather, it has to be taken into account that the narrative settings of the Jesus stories is not just a "frame" from which the traditions should be removed but a historical description serving as the narrative context for Jesus' teaching in parables and wisdom sayings, his healings, his encounters with followers, adversaries and Gentiles, and so forth.' See also Rodríguez (2012:150), who argues that the Gospels are memorial artifacts, coherent instances of the performance of the Jesus tradition that presents images of the historical Jesus.' Clearly Schröter and Rodríguez here equate the referential world of the Gospels with their different textual worlds.

23.As put by Foster (2012:197): 'Hence memory is seen as providing primary insight into the contemporary timeframe when the memory was recollected, rather than when the putative event occurred.'

24.Schröter (2013:29) is thus not correct in his critique that the criteria approach for a long time has interpreted individual units of the tradition of the Gospels 'alongside extensive neglect of the historiographic implications of their literary context.'

25.Ironically Schröter (2013:48), when criticising the criteria approach for disregarding the importance of the Gospels as narratives, fully concurs with this understanding of the Gospels as perspectival interpretations of the historical Jesus in stating the following: The Gospels are 'presentations that interpret the activity of the historical Jesus from a certain perspective. Mark orients himself to the activity of Jesus, which sets up a new framework for the interpretation of reality. Past, present and future are joined with one another in a new way and the person of lesus becomes the center of a conception of history.' Schröter is thus in agreement with the criterio center of a conception of history. Schroter is thus in agreement with the criteria approach in that the Gospels narratives are interpretations of the historical Jesus. Being the case, memory studies, in their quest for the historical Jesus, should take this seriously in their methodology regarding the quest for the
historical Jesus.

26.Keith (2012a:201) is thus not correct when he criticises the criteria approach for not starting the quest for the historical Jesus from the portrayals of Jesus in the available sources, but rather in spite of them. 
new meaning (e.g., Luke's use of the parable of the Friend at Midnight in Lk 11:5-8 or Matthew and Luke's use of the parable of the Lost sheep in Mt 18:12-14 and Lk 15:4-7; see Van Eck 2011a, 2011c). ${ }^{27}$ The frameworks of the Gospel narratives are important for the criteria approach, but must be taken for what they are; frameworks that interpret and create meaning through overall structure and intention ${ }^{28}$ and the placement of individual narratives in a narrative context (plot). Thus, the criteria approach believes, for example, that by identifying multiple versions of the same tradition found in more than one Gospel, and then interpreting these traditions while taking into consideration the redactional activity and overall intent of the Gospel writer, can get us to layers of the tradition used that most probably is closer to the words and deeds of the historical Jesus. ${ }^{29}$

\section{Putting the social memory approach to the test}

In the section above it has been indicated that the criteria and social memory approach's understanding of the Gospel narratives in essence do not differ from one another. While the social memory approach argues that the Gospels are narratives in which the past is reconstructed in light of the needs of the present, the criteria approach argues that the Gospel narratives are textual worlds (the referential world filtered through respective contextual worlds). There is, however, one important difference between the two approaches. While the criteria approach believes that the referential world of the Gospels is present in the written traditions that can be traced back to an earlier layer of the tradition, the memory studies approach believes that the remembered past already impacted the original interpretations of Jesus by his contemporary audience. Also, in spite of understanding the Gospel narratives as refractions of refractions (to use Le Donne's term), the memory studies approach 'view it as an unproblematic means of verifying the reliability of past events' (Foster 2012:202). Foster (2012) continues:

$[A]$ part from the catch-cry that social memory establishes historical reliability, there has been no thoroughgoing application of social memory theory to individual Gospel pericopae in a way that would demonstrate this to be a useful hermeneutical tool for clarifying historicity. In other words, insights from community memory theories have not been shown to add anything to the interpretative task. (p. 202) $)^{30}$

Although we do not have a thoroughgoing application of social memory theory to individual Gospel narratives, as

27.Schröter (2013:33) agrees on this point when he states that events that took place (traditions of the historical Jesus) 'are not identical with their later presentation within the ... narrative.'

28.Again, Schröter (2013:33) agrees in stating that an event of the past, when retold 'is characterized by the perspectival viewpoint of the historian."

29.Schröter (2013:89), in fact, agrees with this when stating that it is not disputed that the Gospel narratives reach back to older traditions which are linguistically and compositionally integrated into the later Gospel narratives (see also Schröter 2013:80).

30.See also Foster (2012:226-227): ' $[W]$ hat is perhaps more troubling than this lack of support for these theories within the disciplines where they originated is the lack of textual examples where social memory theory or orality is applied to sets of traditions in a manner that demonstrates the utility of these methods for historical Jesus research.
Foster indicates, we do have a few examples that can be used to put the social memory approach to the test (see Hooker 2012:xv; Le Donne 2011:48-52, 85-92, 123-129; Rodríguez 2013:5; Schröter 2013:117-130). ${ }^{31}$ Since space does not allow a critical assessment of all these examples, in what follows Schröter's reading of Mark's narrative, aiming to prove the usability of the Gospels for an image of the historical Jesus (verifying the reliability of past events), is discussed. This example is also chosen since it has a direct bearing on the two main points of critique the memory approach levels at the criteria approach, as will be indicated below.

According to Schröter (2013:119-130), Mark's narrative begins by localising the appearances of John and Jesus respectively at the Jordan and in Galilee (attested in Q; see Schröter 2013:120), with Jesus coming from Nazareth to the Jordan to be baptized by John. As such, the narrative preserves 'concrete historical memories about the location of the activity of John, the origin of Jesus, and also his baptism by John' (Schröter 2013:119). In what follows in the narrative, Galilee becomes the scene of Jesus' actions. In Galilee Jesus' activities are linked with the Sea of Galilee, synagogues in Galilee, Nazareth (his hometown), and especially Capernaum as the place of Jesus' activity and 'the place from which Jesus goes to the surrounding villages and the sea to which he always returns again' (Schröter 2013:121). With regard to people, Jesus' disciples, his family and his opponents are introduced early in the narrative. Jesus' activity remains limited to the villages of Galilee, whereas Sepphoris and Tiberias, the important cities in Galilee, are not mentioned. This picture of Jesus, Schröter (2013:124) argues, indicates that Jesus avoided the cities and directed his proclamation of the kingdom of God to the population in the villages (again attested in Q; see Schröter 2013:125). Jesus also undertakes three journeys to neighbouring regions (the land of the Gerasenes, the region of Tyre, Sidon and the Decapolis, and the villages of Caesarea Philippi), most probably seeking out Jewish settlements. These three facets of Mark (Jesus' activity in Galilee, his focus on smaller villages and his journeys to Jewish settlements in neighbouring regions), Schröter (2013:129) concludes, indicate the geographical, religious and cultural context in which the activity of the historical Jesus took place, and localise 'the activity of Jesus where they actually took place' (Schröter 2013:130).

Firstly, it is interesting that Schröter (like Le Donne; see again note 31), in reading Mark's narrative by employing the memory approach to prove the usability of the Gospel narratives for an image of the historical Jesus, uses some

31. Hooker (2012:xv), for example, argues that when one concentrates on the Gospel narratives as a whole rather than on the details, 'we shall find that we know quite a lot about Jesus': Jesus taught in parables, the kingdom of God was central to his message, he befriended those on the outskirts of society, and performed miracles. This will also be the conclusion of the criteria approach. Le Donne (2011:48-52 85-92, 123-129), in tracing Jesus' relationship with his family (Mk 3:31-35. Lk 11:27-28. Thom 79), concludes that Jesus was at odds with his family. To reach this conclusion, he applies the criteria of was at odds with his family. To reach this conclusion, he applies the criteria of coherence and independent, early and multiple attestation (Le Donne 2011:49, 50). See also Rodríguez's (2013:5-6) interpretation of Jesus' saying in Mark 2:17, which, according to him, Mark use in service of a paticular interpretation of Jesus, namely that he associater sinners and tax collectors rather than with scribes and Pharisees. Funk, Hoover and the Jesus Seminar (1993:285), interestingly come to more or less the same conclusion without using a memory studies approach. 
aspects of the methodology of the criteria approach. Not only is Mark described as:

[The] oldest narrative, but $\mathrm{Q}$ is used to support Mark's localization of the activity of John and Jesus and Jesus' avoidance of the cities in Galilee. This is an application of the criteria of early, independent and multiple attestation, and contradicts Schröter's own questioning of 'the alleged multiple attestation as a 'historically appropriate criterion'. (Schröter 1996:158)

With regards to Schröter's reading of Mark's narrative to prove the usability of the Gospels for an image of the historical Jesus, the following: John's Gospel does not depict Galilee as the scene of Jesus' actions. In John, Jesus' activity is depicted as taking place in Galilee and Jerusalem (see Jn $2: 13 ; 6: 4-5 ; 11: 55-56$ ), and John has no narrative of John baptizing Jesus, except for an indirect reference to the baptism (Jn 1:29). Regarding Jesus' hometown being Nazareth, Matthew disagrees (see Mt 2:1; 3:23), and in the narrative of the healing of the paralytic (Mk 2:1-12), Luke's version does not locate the healing in Capernaum (Lk 5:12). Also, the opponents of Jesus being present at this healing are described differently by Mark 2:6 (scribes) and Luke 5:17 (Pharisees and the scribes from every village in Galilee, Judea and from Jerusalem). Moreover, while Jesus' healings in the land of the Gerasenes (Mk 5:1-10), the region of Tyre and Sidon (Mk 7:24-30), the Decapolis (Mk 7:31-37), and his presence in the villages of Caesarea Philippi (Mk 8:27-30) are attested by Matthew (albeit at times only indirectly; see Mt 8:28-34; 15:21-28, 29-31; 16:1321), Luke has no reference to Jesus visiting neighbouring regions. Luke and John, on the other hand, have Jesus travelling through Samaria (see Lk 9:51-53; Jn 4:1-42). These differences, when taken seriously, question Schröter's reading of Mark's narrative as a presentation (historical narrative) of 'people and events from the time of the activity of Jesus' (Schröter 2013:118).

Schröter's reading creates more questions than answers, and does not offer anything new to the problem under investigation. For one, does his reading of Mark imply that some narratives are more 'historical' than others? What about Matthew's revision of the Markan 'chronology'? Should Matthew's chronology, that creates a new narrative thread, also be considered as historical, or is it fictional (see Luz 2005:60-63)? Moreover, the conclusions reached by Schröter are not that different from what the results would be when the micro-narratives he refers to are scrutinised by means of the criteria approach.

\section{Concluding remarks}

Historical Jesus studies using the criteria approach do not make use of form criticism and are not interested in the oral stage of the transmission of Jesus traditions. The Gospel narratives are seen as a window to the world of the historical Jesus, that is, as a crucial link to the past. These narratives, it is believed, made use of written sources for their respective literary portraits (textual worlds) of Jesus. ${ }^{32}$ Since these narratives remember the past for the present thus agreeing with memory studies' understanding of the Gospel narratives - it is also believed that the shaped present (different theologies of interpretations of Jesus for a specific audience) can be indicated in these narratives with the help of redaction criticism. At the same time, criteria are used to identify the traditions most probably used by the Gospel writers. These written traditions, it is believed, existed prior to the Gospels, and represent a layer closer to the historical Jesus than the Gospel narratives. Finally, the identified traditions are used for a portrait of Jesus.

Memory studies, on the other hand, believe that the only sources we have are refractions of refractions. According to this approach, the initial impressions of the eye and ear witnesses of Jesus' deeds and words set into motion interpretations or memories of Jesus that shaped the initial impressions of Jesus (Keith 2011:172). As such, the only sources available to study the historical Jesus are interpretations of interpretations of interpretations. With this understanding of the trajectory of the oral development of the Jesus tradition, memory studies show their formcritical roots and leave the quest for the historical Jesus with no sources to work with. If we believe that we only have interpretations of interpretations, the past shaped in terms of the present with no real idea what the past consisted of, Crook is correct that no quest is possible. The criteria approach did not lead historical Jesus research into a methodological quagmire, but memory studies will. As is usually the case, it is easy to criticise without putting a viable alternative in place, as admitted by Rodríguez (2012), one of the advocates of memory studies:

Of course, formulating the future of post-criteriological Jesus research is a difficult task, and to my mind no one yet has offered a clear and compelling vision of what such research should look like. (p. 149)

\section{Acknowledgements Competing interests}

The author declares that he has no financial or personal relationships which may have inappropriately influenced him in writing this article.

\section{References}

Allison, D.C., 2012, 'It don't come easy: A history of disillusionment', in C. Keith \& A Le Donne (eds.), Jesus, criteria, and the demise of authenticity, pp. 186-199, T \& T Clark International, New York.

Catchpole, D.R., 1997, 'Source, form and redaction criticism of the New Testament', in S.E. Porter (ed.), Handbook to exegesis of the New Testament, pp. 167-188, Koninklijke Brill, Leiden.

Crook, Z., 2013, 'Memory theory and the evolution to a No Quest', paper presented at the Society of Biblical Literature Annual meeting, Memory studies in historical Jesus research, Baltimore, 22-26 November, pp. 1-22.

Crossan, J.D., 1991, The historical Jesus: The life of a Mediterranean Jewish peasant HarperSanFrancisco, San Francisco.

32.'One of the significant challenges from proponents of orality against a literary model is that the levels of variability within the synoptic tradition militate against accepting the notion of the literary transmission of traditions .... [T] he high level accepting the notion of the literary transmission of traditions .... $[T]$ he high level
verbatim agreement in several pericopae ... suggests that a significant amount of material was in fact transmitted in written form' (Foster 2012:207). 
Foster, P., 2012, 'Memory, orality, and the Fourth Gospel: Three dead-ends in historical Jesus research', Journal for the Study of the Historical Jesus 10, 191-227.

Foster, P., 2013, 'Memory: Help or hindrance in historical Jesus study?', paper presented at the SBL Annual meeting, Memory studies in historical Jesus research, Baltimore, 22-26th November, pp. 1-7.

Funk, R.W., Hoover, R.W. \& The Jesus Seminar, 1993, The five Gospels: The search for the authentic words of Jesus, Macmillan, New York.

Goodacre, M., 2012, 'Criticizing the criterion of multiple attestation: The historical Jesus and the question of sources', in C. Keith \& A. Le Donne (eds.), Jesus, criteria, and the demise of authenticity, pp. 152-169, T \& T Clark International, New York.

Hooker, M.D., 1972, 'On using the wrong tool', Theology 75, 570-581.

Hooker, M.D., 2012, 'Foreword: Forty years on', in C. Keith \& A. Le Donne (eds.), Jesus, criteria, and the demise of authenticity, pp. xiii-xvii, T \& T Clark International, New York.

Keith, C., 2011, 'Memory and authenticity: Jesus tradition and what really happened', Zeitschrift für die Neutestamentliche Wissenschaft 102(2), 155-177. http://dx.doi. org/10.1515/zntw.2011.011

Keith, C., 2012a, 'The fall of the quest for an authentic Jesus: Concluding remarks', in C. Keith \& A. Le Donne (eds.), Jesus, criteria, and the demise of authenticity, pp. 200-205, T \& T Clark International, New York.

Keith, C., 2012b, 'The indebtedness of the criteria approach to form criticism and recent attempts to rehabilitate the search for an authentic Jesus', in C. Keith \& A. Le Donne (eds.), Jesus, criteria, and the demise of authenticity, pp. 25-48, T \& Clark International, New York.

Keith, C., 2013, “'Opinion statement' made at session S25-315, presented at the SBL Annual meeting, Memory studies in historical Jesus research', Baltimore, 22-26th November, pp. 1-17.

Keith, C. \& Le Donne, A. (eds.), 2012, Jesus, criteria, and the demise of authenticity, $T$ $\& \mathrm{~T}$ Clark International, New York.

Keith, C., Crook, Z., Rodríguez, R.R. \& Foster, P., 2013, Memory studies in historical Jesus research, audio recording, panel discussion viewed 3 March 2014, from www. http://historicaljesusresearch.blogspot.com/2013/12/memory-studies-inhistorical-jesus_13.html.

Kirk, A. \& Thatcher, T., 2012, 'Jesus tradition as social memory', in A. Kirk \& T. Thatcher (eds.), Memory, tradition, and text: Uses of the past in early Christianity, pp. 2542, SBL, Atlanta. (Semeia Studies 52).

Kloppenborg, J.S., 2008, $Q$ the earliest Gospel: An introduction to the original stories and sayings of Jesus, Westminster John Knox Press, Louisville.

Kloppenborg, J.S., 2012, 'Memory, performance and the sayings of Jesus', Journal for the Study of the Historical Jesus 10, 97-132.

Krentz, E., 1975, The historical-critical method, Fortress Press, Philadelphia. (Guides to Biblical Scholarship).

Le Donne, A., 2011, Historical Jesus: What can we know and how can we know it? William B. Eerdmans Publishing Company, Grand Rapids.

Le Donne, A., 2012a, 'The criterion of coherence: Its development, inevitability, and historiographical limitations', in C. Keith \& A. Le Donne (eds.), Jesus, criteria, and the demise of authenticity, pp. 95-114, T \& T Clark International, New York.
Le Donne, A., 2012b, 'The rise of the quest for the historical Jesus: An introduction to the crumbling foundations of Jesus research', in C. Keith \& A. Le Donne (eds.) Jesus, criteria, and the demise of authenticity, pp. 3-21, T \& T Clark International, Jew York.

Le Donne, A., 2014, 'Jesus Blog: The blow up in Baltimore - why it was disappointing', viewed 07 March 2014, from http://historicaljesusresearch.blogspot. com/2014/03/the-blow-up-in-baltimore-why-it-was.html

Luz, U., 2005, 'Fictionality and loyalty to tradition in Matthew's Gospel in the light of Greek literature', in U. Luz, Studies in Matthew, transl. R. Selle, pp. 54-79, William B. Eerdmans Publishing Company, Grand Rapids.

Rodríguez, R.R., 2012, 'The embarrassing truth about Jesus: The criterion of embarrassment and the failure of historical authenticity', in C. Keith \& A. Le Donne (eds.), Jesus, criteria, and the demise of authenticity, pp. 132-151, T \& T Clark International, New York.

Rodríguez, R.R., 2013, 'An uneasy concord: Memory and history in contemporary Jesus research', paper presented at the Society of Biblical Literature Annual meeting, Memory studies in historical Jesus research, Baltimore, 22-26 November, pp. 1-18.

Schröter, J., 1996, 'The historical Jesus and the sayings tradition: Comments on current research', Neotestamentica 30(1), 151-168.

Schröter, J., 2012, 'The criteria of authenticity in Jesus research and historiographica method', in C. Keith \& A. Le Donne (eds.), Jesus, criteria, and the demise of authenticity, pp. 49-70, T \& T Clark International, New York.

Schröter, J., 2013, From Jesus to the New Testament: Early Christian theology and the origin of the New Testament canon, transl. W. Coppins, Baylor University Press, Waco.

Snodgrass, K.R., 2008, Stories with intent: A comprehensive guide to the parables of Jesus, William B. Eerdmans Publishing House, Grand Rapids.

Stuckenbruck, L.T., 2012, "'Semitic influence on Greek": An authentic criterion in Jesus research?', in C. Keith \& A. Le Donne (eds.), Jesus, criteria, and the demise of authenticity, pp. 73-94, T \& T Clark International, New York.

Tatum, W.B., 1999, In quest of Jesus, Abingdon, Nashville.

Van Eck, E., 2011a, 'In the kingdom everybody has enough - A social-scientific and realistic reading of the parable of the lost sheep (Lk 15:4-6)', HTS Teologiese Studies/Theological Studies 67(3), Art. \#1067, 10 pages.

Van Eck, E., 2011b, 'Social memory and identity: Luke 19:12b-24 and 27', Biblica Theological Bulletin: Journal of Bible and Culture 41(4), 201-212.

Van Eck, E., 2011c, 'When neighbours are not neighbours: A social-scientific reading of the parable of the friend at midnight (Lk 11:5-8)', HTS Teologiese Studies/ Theological Studies 67(1), Art. \#788, 14 pages.

Van Eck, E., 2012 'Eschatology and kingdom in Mark' in J.G. van der Watt (ed.) Eschatology in the New Testament and some related documents, pp. 64-90, Mohr Siebeck, Tübingen. (Wissenschaftliche Untersuchungen zum Neuen Testament, 315).

Winter, D. 2012, 'Saving the quest for authenticity from the criterion of dissimilarity: History and plausibility', in C. Keith \& A. Le Donne (eds.), Jesus, criteria, and the demise of authenticity, pp. 115-131, T \& T Clark International, New York. 